UDC 331.446 .4

\title{
THE ROLE OF EMOTIONAL INTELLIGENCE IN THE WORK OF EXECUTIVES BY DIFFERENT MANAGEMENT LEVELS
}

\author{
Ganna Rekun \\ PhD in Economics, associate professor \\ e-mail: rekun@karazin.ua \\ ORCID ID: 0000-0002-1734-7364 \\ Sofiia Demchenko \\ magistrate \\ e-mail: sofia.demchenko95@gmail.com \\ ORCID ID: 0000-0003-3658-5197 \\ V.N. Karazin Kharkiv National University \\ 1, Mironositskaya Str., Kharkiv, 61002, Ukraine
}

In modern conditions of globalized society in the theories of management, there is growing attention to emotional information, its importance and the need of its effective use. Researches confirm that emotions can act as organizational resources that can be managed to improve organization's effectiveness, employee's performance and create a favorable moral and psychological climate, both within the organization and with external stakeholders. This article studies the main approaches to the application of the concept of «emotional intelligence» among the various levels of management in the organization and offers authors' development to improve competencies in this area. The relevance of the research is proved, which consists in special attention to the problems of exchange and use of emotional information among personnel and management. The basic competences those are necessary for the development of emotional intelligence from a position of importance for different levels of managers are studied. This article analyzes the development and practices of implementing programs to enhance emotional intelligence in international organizations and corporations.

The purpose of the article is to study the influence of emotional intelligence on different levels of managers in order to identify the main areas of competence development.

To achieve the set purpose the following tasks have to be solved: to study the concept of «emotional intelligence», its components; to study the basic competences of emotional intelligence; substantiation of competencies and their importance for managers; to research the best practices on increasing the emotional intelligence in organizations and results of its implementation; to analyze the need to apply and develop emotional intelligence among different levels of management.

Authors use such research methods as analysis and synthesis, abstraction and generalization, comparison and competency-based approach.

The result of the work is developed recommendations for increasing emotional intelligence among executives based on the analysis of the importance of different competencies for different levels of management.

Key words: Emotional Intelligence, Competence of Emotional Intelligence, EI, EQ, Management.

\section{РОЛЬ ЕМОЦІЙНОГО ІНТЕЛЕКТУ В ОРГАНІЗАЦІЇ РОБОТИ МЕНЕДЖЕРІВ РІЗНИХ РІВНІВ УПРАВЛІННЯ}

\author{
Рекун Ганна Петрівна \\ кандидат економічних наук, доцент \\ e-mail: rekun@karazin.ua \\ ORCID ID: 0000-0002-1734-7364 \\ Демченко Софія Вікторівна \\ магістрант \\ e-mail: sofia.demchenko95@gmail.com \\ ORCID ID: 0000-0003-3658-5197
}

Харківський національний університет імені В. Н. Каразіна

вул. Мироносиџька, 1, Харків, 61002, Украӥна

У сучасних умовах суспільства, що глобалізується, у теоріях менеджменту зростає увага до емоційної інформації, іiї важливості та необхідності ефективного використання. Дослідження підтверджують, що емоції можуть виступати як ресурси організації, якими можна керувати задля підвищення ії ефективності, результативності працівників та створення сприятливого морального-психологічного клімату, як всередині організації, так і з зовнішніми зацікавленими особами. У даній статті досліджуються основні підходи до застосування концепції «емоційного інтелекту» серед різних рівнів менеджменту в організації та 
пропонуються власні розробки з підвищення компетенцій у цій сфері. Доведена актуальність дослідження, що полягає в особливій увазі до проблематики обміну та використання емоційної інформації серед персоналу та менеджменту. Вивчаються основні компетенції, які необхідні для розвитку емоційного інтелекту з позиції важливості для різних рівнів управлінців. У даній статті проаналізовані розробки та практики імплементації програм підвищення емоційного інтелекту у міжнародних організаціях та корпораціях.

Мета статті полягає в дослідженні впливу емоційного інтелекту на різні рівні управлінців задля визначення основних напрямків підвищення компетенцій.

Досягнення поставленої мети обумовило вирішення наступних завдань: вивчення поняття «емоційний інтелект», його складових; дослідження основних компетентностей емоційного інтелекту; обгрунтування компетентностей та їхньої важливості для менеджерів; дослідження кращих практик і результатів застосування у сфері підвищення емоційного інтелекту в організаціях; аналіз необхідності застосування та розвитку емоційного інтелекту серед різних рівнів менеджменту.

Автори застосовують такі методи дослідження, як аналіз і синтез, абстрагування і узагальнення, порівняння та компетентнісний підхід.

Результатом роботи є розробка рекомендацій щодо підвищення емоційного інтелекту серед менеджерів на основі аналізу важливості різних компетенцій для різних рівнів управління.

Ключові слова: емоційний інтелект, компетенції емоційного інтелекту, EI, EQ, менеджмент.

\title{
РОЛЬ ЭМОЦИОНАЛЬНОГО ИНТЕЛЛЕКТА В ОРГАНИЗАЦИИ РАБОТЫ МЕНЕДЖЕРОВ РАЗНЫХ УРОВНЕЙ УПРАВЛЕНИЯ
}

\author{
Рекун Анна Петровна \\ кандидат экономических наук, доцент \\ e-mail: rekun@karazin.ua \\ ORCID ID: 0000-0002-1734-7364 \\ Демченко София Викторовна \\ магистрант \\ e-mail: sofia.demchenko95@gmail.com \\ ORCID ID: 0000-0003-3658-5197
}

Харьковский национальный университет имени В.Н. Каразина

ул. Мироносичкая, 1, Харьков, 61002, Украина

В современных условиях общества, которое глобализируется, в теориях менеджмента растет внимание к эмоциональной информации, ее важности и необходимости эффективного использования. Исследования подтверждают, что эмоции могут выступать как ресурсы организации, которыми можно управлять для повышения ее эффективности, результативности работников и создания благоприятного моральнопсихологического климата, как внутри организации, так и с внешними заинтересованными лицами. В данной статье исследуются основные подходы к применению концепции «эмоционального интеллекта» среди различных уровней менеджмента в организации и предлагаются собственные разработки по повышению компетенций в этой сфере. Доказана актуальность исследования, которая заключается в особом внимании к проблематике обмена и использования эмоциональной информации среди персонала и менеджмента. Изучаются основные компетенции, которые необходимы для развития эмоционального интеллекта с позиции важности для различных уровней управленцев. В данной статье проанализированы разработки и практики имплементации программ повышения эмоционального интеллекта в международных организациях и корпорациях.

Цель статьи заключается в исследовании влияния эмоционального интеллекта на разные уровни управленцев для определения основных направлений повышения компетенций.

Достижение поставленной цели обусловило решение следующих задач: изучение понятия «эмоциональный интеллект», его составляющих; исследование основных компетенций эмоционального интеллекта; обоснование компетенций и их важности для менеджеров; исследование лучших практик и результатов применения в сфере повышения эмоционального интеллекта в организациях; анализ необходимости применения и развития эмоционального интеллекта среди различных уровней менеджмента.

Авторы применяют такие методы исследования, как анализ и синтез, абстрагирование и обобщение, сравнение и компетентностный подход.

Результатом работы является разработка рекомендаций по повышению эмоционального интеллекта среди менеджеров на основе анализа важности различных компетенций для разных уровней управления.

Ключевые слова: эмоциональный интеллект, компетенции эмоционального интеллекта, EI, EQ, менеджмент.

Introduction. An issue of managing personnel with a view to reaching a qualitatively new level becomes more urgent in a rapidly changing environment, the ever-increasing flow of information and 
the desire to catch or create a trend. At the forefront are deeply hidden psychological and sociological factors. Its consideration can drastically change the approaches to the management of an organization, the life cycle of the product, corporate culture, etc.

Today, such a trend, capable of changing everything - from the personnel management system to receiving super profits of the company - is developing of the emotional intelligence skills. Modern research shows that the key aspect of management today is the study of emotional intelligence, as it is proved, that emotional information plays a significant role in the professional activity of a person and whole organizations in general. That is why it is necessary to pay considerable attention to the study of emotional intelligence, its influence, the development of soft skills at different levels of management and among the staff as a whole, as this has a significant impact on the personal indicators of employees, results, effectiveness and success of the company.

Literature review. The main researchers in the field of emotional intelligence are Peter Salovey, John Mayer [1; 2], David Caruso [3; 4] whose work had significant impact on the wide spreading and recognizing the importance of studying such component of human existence as emotion. A scientist who studied human brain and behavior - Daniel Goleman, author of the best-selling book «Emotional Intelligence», paid special attention to studying this issue [5].

The aim of the study is to study of emotional intelligence, its main components, the importance and impact on different levels of management and identifying the main areas of competence development.

Key research findings. The widespread and recognized importance of studying such component of human existence as emotion is manifested only in the 90's. of the XX century. At that times Peter Salovey and John Mayer proposed the formal definition of emotional intelligence - «the ability to control one's own and others' feelings, distinguish them and use this information to guide their thinking and actions». Together with David Caruso, they developed the theory of «Emotional Intelligence» and put forward an assumption that is today fundamental - the most important components of emotional intelligence are: the perception of emotions, their using understanding and management [1-4].

Daniel Goleman argued that not the cognitive intelligence guaranteed success in business, but emotional intelligence [5].

Together with the development of the theory of the importance of emotional intelligence, more and more studies have confirmed the validity of the scientists' statements. And more and more such developments have been transferred from the sphere of personal development to wider areas, such as personnel and organization management. Studies show that people with high EQ (Emotional Quotient) have the best level of mental health, exemplary work and stronger leadership qualities. The EQ indicator itself includes $67 \%$ of those traits that were identified as necessary for good performance and are twice as important as technical expertise or IQ [5].

The development of a higher level of emotional intelligence allows one to cope with uncertainty much more better, facilitate decision making, and be more competent in social and personal life circumstances. These skills are especially important in the field of personnel management for all levels of management. Because in this way, a single, powerful and effective organism is formed on the site of an organization, which not only receives super profits, is more competitive and viable, but at the same time pays attention to every employee with his needs [6].

Both managers and staff can benefit from improving their EI level to lead project teams, influence people, and manage internal and external customers more efficiently. When people have high level of emotional intelligence, they make better not only their leaders, but also team members [7].

It is important to understand how and at what level of management exactly it is worth paying attention to one or another competence of emotional intelligence for organizing the most effective work, meeting the needs for self-realization and success, building effective communication chains both inside the organization and with the external environment.

To do this, main components of emotional intelligence should be considered (Fig. 1).

The first component of emotional intelligence - perceiving emotions - is the ability to detect and decipher emotions in faces, pictures, voices and cultural artifacts. It also includes the ability to identify one's own emotions. Perception of emotions can be the most basic aspect of emotional intelligence, as it makes possible any other processing of emotional information.

The second component of emotional intelligence - using emotions - is the ability to use emotions to facilitate various cognitive actions, such as thinking and problem solving. Being in a slightly sad mood helps people to conduct a thorough, methodical work. On the contrary, a happy mood can stimulate creative and innovative thinking. An emotionally intelligent person can make full use of his volatile moods to best approach the task. 


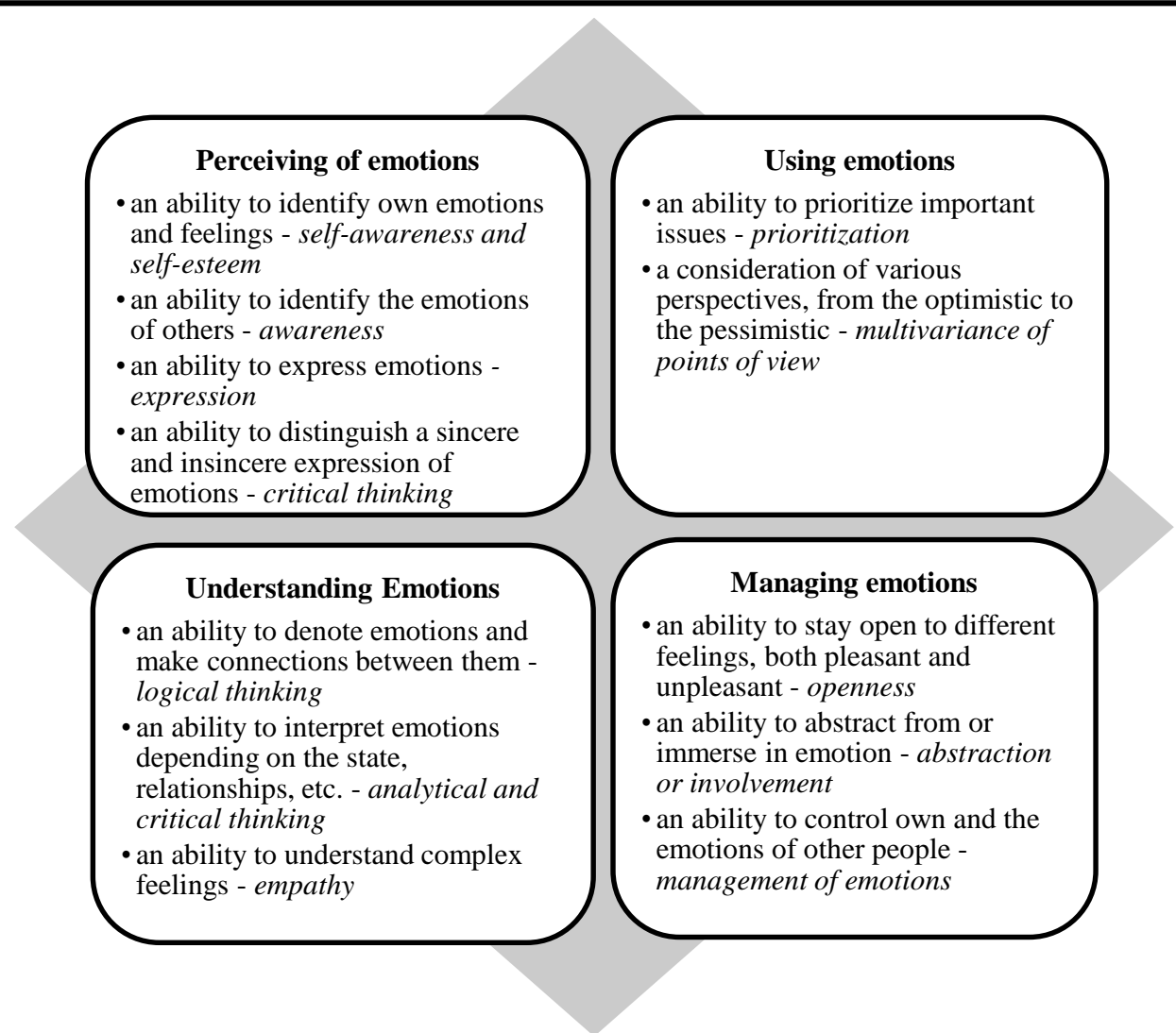

Figure 1 - Competences of emotional intelligence depending on its structure

Source: based on [1-4]

The third component of emotional intelligence - understanding emotions - is the ability to understand the language of emotions and appreciate the complex relationship between emotions. For example, the understanding of emotions includes the ability to be sensitive to minor differences in emotions, like being happy and being in complete ecstasy. In addition, it includes the ability to recognize and describe how emotions develop over time, for example, how shock can turn into grief.

The fourth component of emotional intelligence - management of emotions - consists of the ability to regulate emotions both in people themselves and in others. It is needed to learn how to control own emotions. This branch also includes the ability to control the emotions of others. For instance, an emotionally intelligent leader can strengthen his own anger and use it to utter a powerful speech in order to awaken righteous anger in others. Therefore, a person with a high level of EQ can use emotions, even negative ones, and manage them to achieve their goals [3].

To study the influence of emotional intelligence on different levels of management in personnel management further, it is necessary to consider the content of EI components from the point of view of executives of different levels (Fig. 2).

It is necessary to understand that for the most qualitative development of a high emotional and intellectual environment for staff, different levels of management should pay attention to the development of different priority competencies (Fig. 3).

For low-level managers, the presence and development of such competencies as emotion perception and understanding of emotion is important because they are most likely to be in contact with employees and should be able to feel their emotional mood, elevated or lowered emotional background for more effective management and transfer the relevant information up the steps of management.

Particular emphasis should be placed on developing the competences of emotional intelligence for mid-level managers, since they are an important part of any business as they directly link the executive level with the staff of the front line. Support and involvement of middle management are needed to manage changes in organization successfully. It is essential to have developed social skills and ability to manage these emotions from the lower level, since these managers organize the work of the departments and have an impact on the work of the team. It is important to take into account that often top management is pushed out of middle managers, therefore the development of emotional intelligence in a complex way is a vital skill that ensures the transition to the next stage in management. 


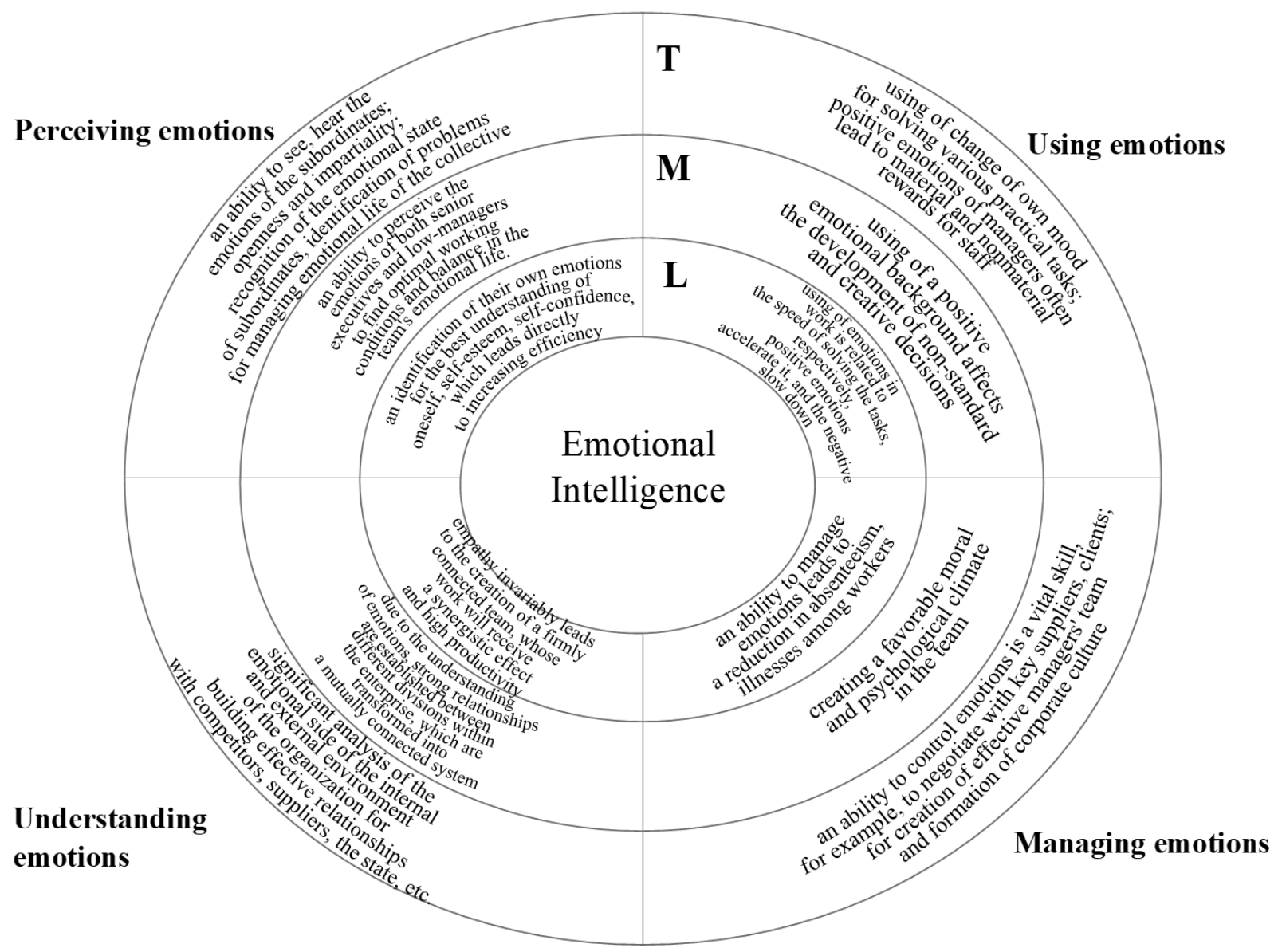

Figure 2 - Content of emotional intelligence components in terms of importance for executives of different levels of management

For top managers, self-development and self-improvement, as leaders of one or another organization, are important for inspiring staff to work not for the sake of getting money, but for following the mission of companies. It is also important to develop a strategic vision, create partnerships and work with the environment. The ability to leave space for other team members, to open up themselves is a feature of an emotionally intelligent manager of the highest level. Emotional intelligence allows the manager to use different models in his guide, but at the same time, react sensitively and quickly to what is happening and to solve any critical situations [8].

One of the critical situations in an organization that may arise is conflicts of a different nature and different orientations. Managers with high emotional intelligence EQ are clearly more effective in resolving conflicts than those with low EQ in management personnel. Often, the problem of many conflict management programs lies not in the tools itself, but in NOT focusing on the development of emotional intelligence skills. According to scientists, the reluctance to analyze the emotional experiences of the parties in the conflict and the low ability to manage their emotions lead to a decrease in the level of criticality to their behavior, a decrease in the level of responsibility for their actions, the lack of an installation on constructive dialogue and a decrease in the sensitivity to the experiences of the opponent. The choice of a suppression strategy in a conflict resolution situation does not require the head of the skills that make up the essence of emotional intelligence. Managing emotions allows you to objectively assess the opportunities and risks of using different conflict resolution strategies. Work with the conflict turns into work with the problem, gaining a constructive orientation, which is most clearly expressed in the model of cooperation.

The importance of increasing the emotional intelligence in organizational culture among management and staff is manifested in the constant attention of Western scientists on this issue. As far as Ukraine is concerned, our country, unfortunately, has not yet come up with a comprehensive study of this issue and very little attention is paid. Abroad such studies are conducted even by organizations. So, in 1996, with the support of the Fetzer Institute, a Consortium for research on emotional intelligence in organizations 
was created. The mission of EI Consortium is to promote research and practice of emotional and social intelligence in organizations through the generation and exchange of knowledge. The Consortium for Research on Emotional Intelligence in Organizations (CREIO) currently consists of 12 core members and 102 additional members who are successful professionals in this field [2]. One of the first projects of the Consortium was aimed at identifying empirically-supported models of best practice for the development of emotional intelligence. The results of the researches led to the creation 15 such models, which include courses on self-management, stress management, interpersonal conflict management, management of interaction and relationships, training on motivation, development of competences of emotional intelligence, etc. [9].

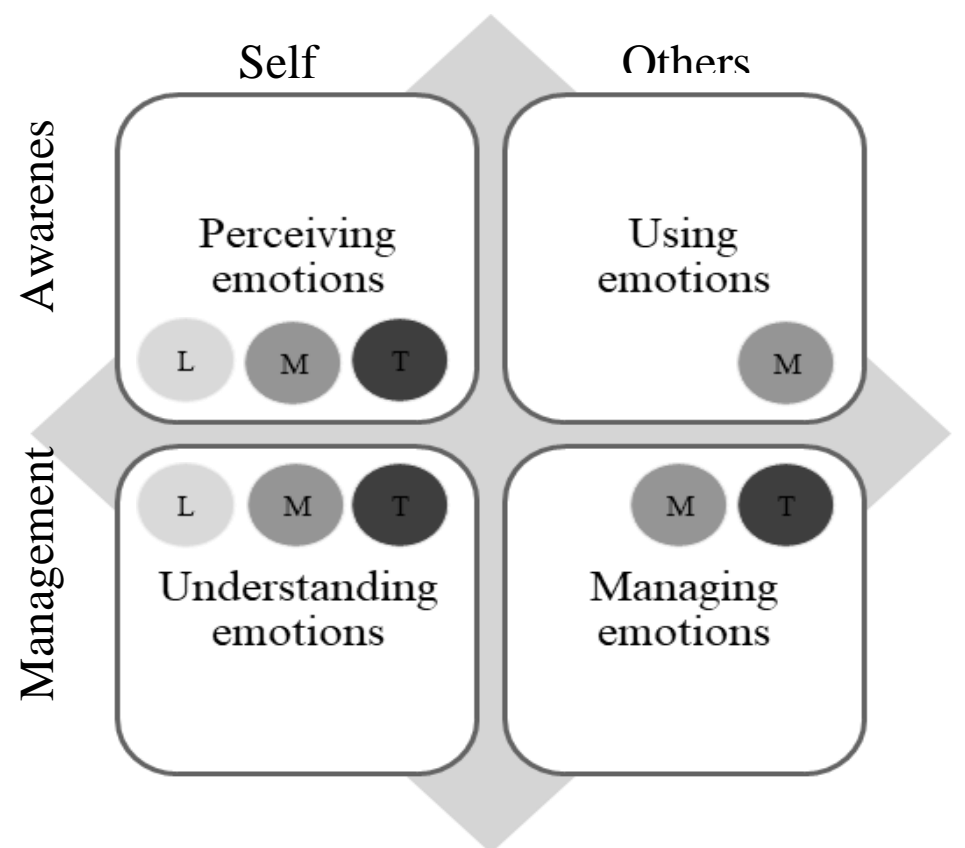

Figure 3 - Focus on competencies for different levels of management ( $\mathrm{T}$ - top management, $\mathrm{M}$ - middle management, $\mathrm{L}$ - lower-management)

One of the most successful examples of implementation programs for evaluating and developing emotional intelligence skills is the experience of the FedEx Express team and their Global Learning Institute. This 6-month course was aimed at top-managers, people-oriented leaders around the world. The main tests were conducted in 2005, 2009, 2010 and 2014. This program provided an 8-11\% increase in core leadership skills, with over half of the participants experiencing very high (10-50\%) improvements in some of the key skills of emotional intelligence and leadership outcomes. $72 \%$ of program participants experienced significant improvements in decision making; $60 \%$ - in a life, and $58 \%$ - a significant improvement in the influencing [10]. These results prove the impact of emotional information on the quality of doing business and, overall, the quality of life, and confirm the thesis that leadership means communication between people at the emotional level.

The main achievement of the research was the creation of a training program, the core component of which was the concentration on the development of emotional intelligence skills - Six Seconds of Emotional Intelligence Assessment (SEI). According to the experiments, it was proved and substantiated the necessity to use emotional intelligence skills on a daily basis.

Another example of the significance of emotional intelligence in management has shown in a Deloitte's report on the necessary features for inclusive leadership. This report builds on the experience of communicating and researching over 1,000 world leaders and 1,500 employees on their perception of inclusive leadership [11]. This leadership should be based on the inclusion of 6 signature traits into the model of behavior of top management. These features, as well as their components, are presented in Appendix C. The surveys substantiate the importance of possessing these traits as a necessary powerful tool for emotional intelligence that allows leaders to work more effectively in different markets, adapt to change, have better communication with the internal and external environment, and encourage staff to realize their potential as fool as possible.

In support of the special influence of emotional intelligence on different areas of the company, in 2015 Harvard Business Review published an article that proves a strong link between empathic leaders and 
financial indicators. The editors have provided evidence indicating the complex nature of our rational and emotional self, as well as the impossibility and inexpediency of dividing these two fields while working [12].

Also, to support of the importance of the development of emotional intelligence among staff and management, the Davos Economic Forum Report «The Future of Jobs» said about the future of professions and the definition of the necessary skills by 2020, among which the emotional intelligence and its main competences, such as sociability, ability to work in a team, empathy etc. [13].

As for Ukraine, according to the results of the survey of companies and the data of the vacancy database in 2015 , there is a significant demand for cognitive skills in our country, however, companies today, regardless of the sphere of activity, generally require young professionals to have soft skills. According to research results, the ratio of the importance of skills soft skills and hard skills, which is optimal for recruitment of young professionals, is $61 \%$ and $39 \%$ respectively. The most important, according to employers, is the ability to assume responsibility $-62,1 \%$, the attempt to develop $-56,9 \%$, persistence $48,3 \%$, sociability $-51,7 \%$. The need for these skills for companies will continue until 2030, where the greatest need, according to the representatives of companies, will be precisely in the developed emotional intelligence, as a combination of the necessary competencies of personal and interpersonal development [14].

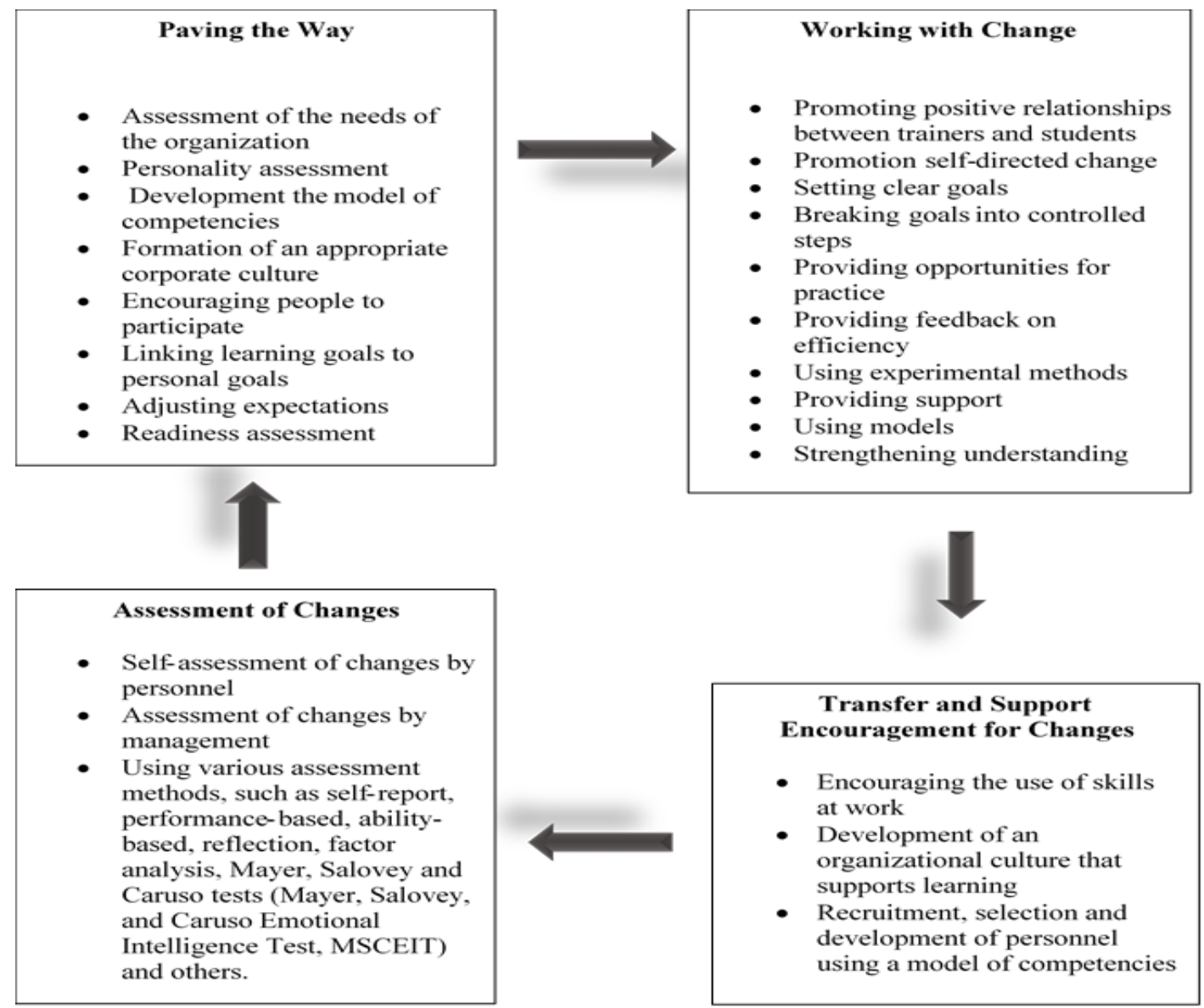

Figure 4 - Guidelines for improving the emotional intelligence in organizations Source: based on [9; 17]

In a 2017 EY study on strategic prospects in Ukraine's labor market, one of the most needed competences in the next 3 years are socio-emotional skills - 56\%, compared with cognitive $-83 \%$ and technical $-50 \%$. The company's research also highlights the importance of employee engagement, which consists of emotional and active components, and directly affects customer satisfaction and company performance $[15 ; 16]$.

After studying the experience of development and management of emotional intelligence, we can propose practical recommendations for its development in organizations. The recommendations are presented in the form of a scheme with a breakdown into the main four phases: preparation, training, exchange maintenance at the same level and assessment (Fig. 4). 
This scheme reveals practical steps toward leadership in each phase of how to promote and enhance the emotional intelligence in the workplace. They are applicable in organizations where developmental, social and emotional learning efforts are being implemented. These guidelines mainly include the use of entrepreneurship efforts, as well as training in control skills, diversification, teamwork, leadership, conflict management, stress management, and so on.

Conclusions. Thereby, it has been proved that for all levels of management it is important to develop an emotional intelligence, since it significantly affects the work of the staff, the environment in the team, the achievement of the necessary results, the expansion of the activity and construction of the organization's image. EI especially important today when executives have to face most of their working time with force majeure, in which the emotional component prevails. Managers should perceive and understand emotions, use and manage them to motivate themselves and their staff. Managers who take the time to learn and truly listen to their employees, make the most of emotional intelligence as an instrument in building a management strategy. Most employees value this attitude and work more efficiently, listening to their boss. They are more loyal to their company. The emotional intelligence allows managers to see in their employees the satisfaction of the conditions, their ability to cope with the set tasks, which teams will be more able to work, or can they achieve the desired tasks. The application of emotional intelligence in management will allow us to reach new heights of the company and will significantly increase the efficiency of the staff.

\section{Література}

1. Mayer J. D., Salovey P. What is emotional intelligence? Emotional development and emotional intelligence: Educational implications // New York: Basic Books. 1997. P. 3-31.

2. Salovey P., Grewal D. The Science of Emotional Intelligence // American Psychological Society. 2005. URL : http://citeseerx.ist.psu.edu/viewdoc/download?doi=10.1.1.385.2439\&rep=rep1 \& type $=$ pdf (дата звернення: 20.04.2018).

3. Mayer J. D., Salovey P., Caruso D.R. Emotional Intelligence Meets Traditional Standards for an Intelligence // Intelligence. 1999. № 27. P. 5-27.

4. Mayer J. D., Salovey P., Caruso D. The Mayer-Salovey-Caruso Emotional Intelligence Test (MSCEIT) // Multi-Health Systems. 2002.

5. Goleman D. Working with Emotional Intelligence // New York: Bantam Books. 1998. 383 p.

6. Rekun G., Sardak Y., Pastukhova N. Innovative changes in human resource management in terms of economic turbulence in Ukraine // Social Economics. 2015. № 2. P. 162-168.

7. Рекун Г. П., Меденець В. В. Емоційне лідерство в системі управління персоналом // Економіка та суспільство (електронне наукове фахове видання). 2017. № 13. С. 691-696. URL : http://economyandsociety.in.ua/journal/13_ukr/117.pdf (дата звернення: 20.04.2018).

8. Книш А. С. Емоційний інтелект лідера у сфері бізнесу : навчальний посібник. К. : ДП «НВЦ «Пріоритети». 2016. 40 с.

9. Consortium for Research on Emotional Intelligence in Organizations. URL : http://www.eiconsortium.org/index.html (дата звернення: 20.04.2018).

10. Freedman J. Case Study: Emotional Intelligence for People-First Leadership at FedEx Express // Six Seconds. The Emotional Intelligence Network. 2014. URL : http://www.6seconds.org/2014/01/14/case-study-emotional-intelligence-people-first-leadershipfedex-express/ (дата звернення: 22.04.2018).

11. Bourke J., Dilon B. The six signature traits of inclusive leadership // Deloitte Insights. 2016. URL : https://www2.deloitte.com/insights/us/en/topics/talent/six-signature-traits-of-inclusiveleadership.html (дата звернення: 22.04.2018).

12. Ovans A. How Emotional Intelligence Became a Key Leadership Skill // Harvard Business Review. 2015. URL : https://hbr.org/2015/04/how-emotional-intelligence-became-a-keyleadership-skill (дата звернення: 20.04.2018).

13. Global Challenge Insight Report «The Future of Jobs» // World Economic Forum. 2016. URL : http://www3.weforum.org/docs/WEF_Future_of_Jobs.pdf (дата звернення: 22.04.2018).

14. Навички для України 2030 : Погляд бізнесу // Центр «Розвиток КСВ». 2016. URL : http://csr-ukraine.org/wp-content/uploads/2016/10/\%D0\%9D\%D0\%B0\%D0\%B2\%D0\%B8\%D1 \%87\%D0\%BA\%D0\%B8_2030.pdf (дата звернення: 20.04.2018).

15. Стратегічні перспективи розвитку ринку праці України // EY. 2017. URL : https://www.ey.com/Publication/vwLUAssets/EY-kyiv-post-EY-strategic-outlook-for-theukrainian-labor-market/\$FILE/EY-kyiv-post-EY-strategic-outlook-for-the-ukrainian-labormarket.pdf (дата звернення: 22.04.2018). 
16. Методологія дослідження рівня залученості співробітників // EY. 2017. URL : https://www.ey.com/Publication/vwLUAssets/ey-employee-engagement-survey-metodologyukr/\$FILE/ey-employee-engagement-survey-metodology-ukr.pdf (дата звернення: 22.04.2018).

17. Why Do You Need Emotional Intelligence at Work? // HR in Asia. 2017. URL : https://www.roberthalf.com/research-and-insights/workplace-research/emotional-intelligence-atwork (дата звернення: 20.04.2018).

\section{References}

1. Mayer, J.D., Salovey, P. (1997). What is emotional intelligence? New York: Basic Books.

2. Salovey, P., Grewal, D. (2005). The Science of Emotional Intelligence. American Psychological Society. [online] Available at: http://citeseerx.ist.psu.edu/viewdoc/download?doi=10.1.1.385. $.2439 \&$ rep=rep1\&type $=$ pdf [Accessed 20 Apr. 2018].

3. Mayer, J.D., Salovey, P., Caruso, D.R. (1999). Emotional Intelligence Meets Traditional Standards for an Intelligence. Intelligence, 1999, 27, pp. 5-27.

4. Mayer, J.D., Salovey, P., Caruso, D. (2002). The Mayer-Salovey-Caruso Emotional Intelligence Test (MSCEIT). Multi-Health Systems.

5. Goleman, D. (1998). Working with Emotional Intelligence. New York: Bantam Books.

6. Rekun, G., Sardak, Y. and Pastukhova, N. (2015). Innovative changes in human resource management in terms of economic turbulence in Ukraine. Social Ecomomics, 2, pp. 162-168.

7. Rekun, G.P. (2017). Emotional leadership in the personnel management system ["Emotsiine liderstvo v systemi upravlinnia personalom"]. Economics and Society (electronic scientific professional edition), 2017, 13, pp.691-696. [online] Available at: http://economyandsociety.in.ua/journal/13_ukr/117.pdf [Accessed 20 Apr. 2018].

8. Knysh, A. E. (2017). Emotional intelligence leader in business ["Emotsiinyi intelekt lidera u sferi biznesu”]. Kyiv: Research and Production Center «Priorytety».

9. Consortium for Research on Emotional Intelligence in Organizations. [online] Available at: http://www.eiconsortium.org/index.html_[Accessed 20 Apr. 2018].

10. Freedman, J. (2014). Case Study: Emotional Intelligence for People-First Leadership at FedEx Express. Six Seconds. The Emotional Intelligence Network. [online] Available at: http://www.6seconds.org/2014/ 01/14/case-study-emotional-intelligence-people-first-leadership-fedex-express/ [Accessed 22 Apr. 2018].

11. Bourke, J. and Dilon, B. (2016). The six signature traits of inclusive leadership. Deloitte Insights. [online] Available at: https://www2.deloitte.com/insights/us/en/topics/talent/six-signature-traitsof-inclusive-leadership.html [Accessed 22 Apr. 2018].

12. Ovans, A. (2015). How Emotional Intelligence Became a Key Leadership Skill. Business Review. [online] Available at: https://hbr.org/2015/04/how-emotional-intelligence-became-a-keyleadership-skill [Accessed 20 Apr. 2018].

13. www3.weforum.org. (2016). Global Challenge Insight Report «The Future of Jobs». World Economic Forum. [online] Available at: http://www3.weforum.org/docs/WEF_Future_of_ _Jobs.pdf [Accessed 22 Apr. 2018].

14. Centr «Rozvytok «KSV». (2016). Navychky dlia Ukrainy 2030:Pohliad biznesu. [online] Available at: Retrieved from: http://csr-ukraine.org/wp-content/uploads/2016/10/\%D0\%9D\%D0\%B0\%D0\%B2 \%D0\%B8\%D1\%87\%D0\%BA\%D0\%B8_2030.pdf [Accessed 20 Apr. 2018].

15. www.ey.com. (2017). Strategic prospects for the development of the Ukrainian labor market ["Stratehichni perspektyvy rozvytku rynku pratsi Ukrainy-2017"]. EY. [online] Available at: https://www.ey.com/Publication/vwLUAssets/EY-kyiv-post-EY-strategic-outlook-for-theukrainian-labor-market/\$FILE/EY-kyiv-post-EY-strategic-outlook-for-the-ukrainian-labormarket.pdf [Accessed 22 Apr. 2018].

16. www.ey.com. (2017). Methodology of studying the level of employee engagement ["Metodolohiia doslidzhennia rivnia zaluchenosti spivrobitnykiv"]. EY. [online] Available at: https://www.ey.com/Publication/vwLUAssets/ey-employee-engagement-survey-metodologyukr/\$FILE/ey-employee-engagement-survey-metodology-ukr.pdf [Accessed 22 Apr. 2018].

17. www.roberthalf.com. (2017). Why Do You Need Emotional Intelligence at Work? HR in Asia. [online] Available at: https://www.roberthalf.com/research-and-insights/workplaceresearch/emotional-intelligence-at-work [Accessed 20 Apr. 2018].

Стаття надійшла до редакції 24.04.2018. 